\title{
The effect of perceived value-in-use in advocacy behavior of private higher education institutions in Malaysia: A conceptual paper
}

\author{
DP Christabel Karunanayaka ${ }^{1}$, Lawrence Arokiasamy ${ }^{1}$, and Ridzuan Masri ${ }^{1}$ \\ International University of Malaya-Wales, Faculty of Business and Law, 50480 \\ Tun Ismail, Kuala Lumpur
}

\begin{abstract}
In recent years, there has great deal of attention towards customer value since the concept of value creation prompted in the Service-Dominant (S-D) Logic in marketing theory (Vargo \& Lusch, 2004). With that, one of the aspects that is crucial is building and maintaining relationships that prepares customers for future co-creations. In context of higher education institutions (HEIs), students move from one life cycle stage to another, thereby needs and expectations also evolve, and when they graduate, it may dissolve. With service innovations, a smart active relationship between students and HEIs should be part of any institutions internal branding efforts. As institutions delve into relationship with students, their focus on co-creation with an aim to translate students to advocates, someone who will spread the positive word-of-mouth, defend the brand, and most importantly to feel a sense of responsibility to represent the brand, when need arises. This calls for HEIs to not only manage exchange processes in their internal branding efforts, but also focus on students' perceived value-in-use (ViU). The purpose of this paper is to explore perceived $\mathrm{ViU}$ of students at private HEIs, from the effects of extra-role behavior, trust, self-brand connection and brand prominence towards influencing students to engage in advocacy

behavior.
\end{abstract}

\section{Introduction}

In a world where digital technologies has allowed consumers to interact and share information, knowledge has become a key resource to any higher education institutions (HEIs) that have come to realize to importance of customer advocacy behavior. It has become inevitable for HEIs to focus on the key role students' play as internal catalyst for change (Warwick, 2016). The concept of co-creation has

\footnotetext{
*Corresponding author: kchristabell@gmail.com
} 
been recently conceptualized (Vargo \& Lusch. 2004), and it has shifted the power of a brand to co-creating with customers. Now, with this new perspective, customers are treated as 'proactive co-creators' as well as facilitators of the value co-creation process, which is part of the precept of Service-Dominant logic, better known as SDL in marketing theory (Payne \& Frow, 2011).

According to the Balance theory, to build and maintain powerful brands, a stronger focus on internal stakeholders is needed for consistency between brand perspectives and customer attitude (Garas, Mahran \& Mohamed, 2018). This is especially crucial due to phenomenon changes in the concept of a brand, whereby it is moving away from firm-provided property of goods to brand as a collaborative in the value cocreation activity of firms and all of their stakeholders (Mez, Yi \& Vargo, 2009).

However, the way in which students form their perception especially towards use experience has always been an issue. With the customer path that has changed explicitly especially due to the digital revolution in Asia, the advocacy behavior is stronger than any marketing campaign (Lawer \& Knox, 2006). In fact in a recent book release titled New Wave in marketing, in the post connectivity era, people are moving away from messages from advertising and are dependent on word-of-mouth reviews, recommendations and advises given by students who are either currently experiencing or experienced the usage consumption (Kotler, Kartajaya \& Hooi, 2017). In fact the rate of mechanical and scientific advancement has made it easier for students to build community regardless of their geographical boundaries (Park et al. 2010). It was reported in 2015, $40 \%$ of population in Asia uses internet, while $93 \%$ are mobile users. These numbers shows that digitalization in Asia is aggressive and in Malaysia, $67.5 \%$ of users in Malaysia uses internet users are 137\% (one user may have more than one phone line) (Kotler et al. 2017) In the post connectivity era, customers' loyalty today is no longer characterized by retention and repurchase, but rather by customer recommendation to others (Kotler et al. 2017). Hence the willingness to give recommendations of a brand indicates that the customer has high confidence in the brand in the form of trust. But this can also have negative consequences if the brand identity does not live up to the promises, then customers brand image may be falsely perceived.

In Malaysia, $42 \%$ of HEIs are private for-profit landscape institutions with a student population of close to 624,000 students out of 1.3 million (Tapsir, 2016). In developed economies such as England and USA, private higher education providers constitute approximately 33\% (England) and USA (23.4\%), a number considerably lower than Malaysia. With more than 500 private providers (386 colleges and 23 university colleges and 71 universities) in Malaysia, making this a very crowded field (Teng, 2016). Hence, the challenges today is to also encourage students to be involved in future co-creation, as part of their perceived value-in-use with other stakeholders, as part of strategic tool for improving overall brand image and value of the HEIs (Anholt, 2010 ; Phadke \& Bhagwat, 2011).

When it comes to understanding relationship between perceived value and advocacy rates, many researchers have included different variables to such as autonomy, relatedness, competence (Jillapalli \& Wilcox, 2010), satisfaction (Susanta, Alhabsji, Idrus \& Nimran, 2013), self-brand connection (Kemp, Childers \& Williams, 2012). More than 90 percent of customers identify word-of-mouth as 
the best, most reliable and relevant source of ideas and information about products and services (Lowenstein, 2012). This act of advocacy behavior is mostly voluntary and beyond the control of the service provider, but it is necessary towards the contribution of a brand value. Thus, perceived $\mathrm{ViU}$ is a concept that need to be explored further and this has means towards brand value. In previous studies on value co-creation from a relational perspective, the focus is mainly on variables such as trust, value, communication or loyalty (Sanchez-Fernandez, Iniesta-Bonillo, Schlesinger-Diaz \& Rivera-Torres, 2010). Then, later extended it incorporating additional variables such as quality of the interaction, trust, image, satisfaction and loyalty. However, this aims to extent the works of this study towards the outcome of one of the dimensions of customer citizenship behavior, which is advocacy.

\subsection{Research Question}

What are the factors in perceived value-in-use that influences the likelihood to engage in advocacy behavior among students in private higher education institutions in Malaysia?

\subsection{Literature Review}

\subsection{Customer advocacy behavior}

Traditionally the approach taken in building strong brands is by moving customers through the sales funnel of awareness, consideration, preference, purchase and loyalty. But in today's competitive and digital revolutionary environment, brands want to encourage their customers and potential customers to actively engage as advocates (Kotler et al. 2017). Advocates who engages in advocacy behavior projects the likelihood to advocate a brand to their friends and acquintances, and is found to be far more important than either brand image or brand satisaction in predicting growth (Kirby \& Marsden, 2016) and brand value (Merz et al. 2009). Similar to the concept of word-of-mouth (WOM) advocacy, is an important driver of business growth and profitability (Lovelock \& Wirtz, 2007). While WOM is defined as "informal communication directed at other consumers about the ownership, usage or characteristics of particular goods and service and/or their seller", advocacy behavior is more specific than WOM which includes promotion (Walz \& Celuch, 2010). In fact advocacy behavior is one of the aspects of customer citizenship behavior (Yi \& Gong, 2013). Due to critical importance of word of mouth advocacy, it is pivotal for brands to leverage on service innovation by using social platforms to super-charge their advocates (Fugetta, 2012). In the context of HEIs, it is no doubt that the overall strategic direction of marketing should focus on optimizing the likelihood of students recommending brand to each other and other stakeholders, rather than advertising campaigns, promotional offers, PR or any other marketing initiatives (Fugetta, 2012). However, the task of building advocates is rather complex and difficult as it is dependent on perceived customer value.

With the changes in customer path, the landscape in post connectivity era has experience three shifts have taken place: firstly consumers are influenced by "community" surrounding them towards final attitude; secondly loyalty is ultimately defined as willingness to advocate for the brand; thirdly dialogues and 
connections can either strengthen or weaken the brand appeal (Kotler et al. 2017). The authors' further concur the focus on "care" must be part of any HEIs standard operating procedure (SOP) and most importantly processes must tend to more horizontal, focusing on "collaboration". This means that customers are now not treated as kings, but rather as a friend (Kotler, Kartajaya \& Setiawan, 2016). In fact, the Triangle of Trust in the Advocacy system links brands to brand advocates, brand advocates to prospects through recommendation and eventually prospects to brands. All three are connected and communicate with each other and provides equal value in terms of reward, recommendation and eventually revenue.

Nevertheless, influencing customers towards becoming advocates who will take a personal stake towards brand endorsement and authentic enthusiamsm that influences potential customers to trust the brand can be a challenging one (Fugetta, 2012). Futhermore, customers today are turning to internet to share their thoughts, anxities, personal stories and even seeking comfort from other peoples, and this in turn will inflluence the attitude and behavior towards a brand. This shows that customers today can also co-create by influencing how other customers perceive the brand and with this powerful role, they are some level of control in determing the success of modern brands (Payne, Storbacka, Frow \& Knox, 2009; France, Merrilees \& Miller, 2015 ; Garas et al. 2018 ; Gronroos \& Voima, 2013). Research shows that $91 \%$ of people use a brand recommended by users derived partly from credibility, hence it shows with high word of mouth advocacy rate (ie: likelihood of brand recommendation), the brand grows faster in comparison with low word of mouth advocacy (Kirby \& Marsden, 2016). However, researches on customer advocacy is relatively few as most studies tend to utilize the global view of it being a construct of word-of-mouth (WOM) and brand loyalty. But now with the emergence of SDL, a new perspective of value-in-use has paved an avenue to understand the willingness of customer advocacy behavior, especially now it is recognized as part of studies on customer citizenship behavior (Yi \& Gong, 2013). With that, it is important to explore aspects of perceived value-in-use that influences students towards the willingness to advocate on behalf of the brand.

\subsection{Perceived value-in-use in Service-Dominant Logic (SDL) perspective}

Creating value from a customer co-creation value standpoint has been recognized as a current key concept in marketing, especially since the concept of value creation in SDL of marketing has emerged (Gronroos \& Voima, 2013 ; Vargo \& Lusch, 2004). Since then, consumers are no longer seen as passive purchasers of the brand, but rather are active participant in creating brand experiences (Prahalad \& Ramaswamy, 2000 ; Vargo \& Lusch, 2004). In lieu of that, customers today, especially in service oriented organizations play a powerful role in determining the success of the brand (France et al. 2015). Hence today we look at the deeper understanding of perception.

While perception refers to the way in which an experience is understood or interpreted (Rosenbaum-Elliot, Percy \& Pervan, 2011), value-in-use is an experiential evaluation throughout the service process, hence it can be captured positively or negatively (Medberg, 2016). It is the "the customer's experiential 
evaluation of the product or service proposition beyond its functional attributes and in accordance with his/her individual motivation, specialized competences, actions, processes, and performances" which is the emphasis in age of advocacy (Edvardsson, Enquist \& Johnston, 2010). With that, value-in-use emerges (or is created) through the user's accumulating experiences with resources, processes (and/or their outcomes) in social, physical, temporal and/or spatial contexts, and hence, value creation is here defined as the customer's creation of value-in-use (Ranjan and Read, 2016). Value is only determined when it is in use, regardless whether it is before, during or after the consumption period.

In the service marketing and branding literature, the focus of customer engagement is evidently shifting from firm-brand relationship towards stakeholderfocus era. With the support of the foundational premises of S-D logic, it was evolved to brand logic which conceptualizes all stakeholders form network relationship with brands and interact socially with other stakeholders (Merz et al. 2009). This clearly shows that today's customers want to market with the company, seeking a role as a "partial employee", "working consumer" or "change agent" (Payne et al. 2009 ; Vargo \& Lusch, 2004 ; Xie, Bagozzi \& Troye, 2008). The relationship marketing literature relates to variables such as trust, value, communication, image or loyalty (Morgan \& Hunt,1994; Sanchez-Fernandez et al. 2010). These variables are important construct to the development of a long-term relationship with stakeholders. But with the emergence of S-D Logic emphasizing on co-creation, the concept of value changed. Hence, "Customers do not buy goods or services; they buy offerings which render services which create value.....this shift in focus to services is a shift from the means and the producer perspective to the utilization and the customer perspective"(Vargo and Lusch, 2004).

This is an important perspective to perceive ViU is only realized by and in the context of the life of the consumer. Though it is recently only realized, who stated "what people desire is not products but satisfying experiences" (Medberg, 2016). Then, it was extended by the statement "phenomenological determined by the beneficiary" (Vargo \& Lusch, 2011). It is through customer experiences, the use value is generated (Ranjan and Read, 2016). Research shows that this approach downplays the role of products and services in generating value for the customer, and instead focuses on experiences resulting from the use of the product and services, and this is how these experiences generate value-in-use (Medberg, 2016).

One of the attractions of S-D logic is that customers are not seen as simply passive receivers of value but "as possessors of operant resources.....that they integrate to create experiences and value" (Baron, Patterson, Warnaby \& Harris, 2010 ; Walz \& Celuch, 2010). In other words, they are seen as active participants in the integration of resources as part of a network of actors (Vargo \& Lusch, 2011). While it was focus on both service providers to involve customers in developing the value proposition itself, but it was later argued for long term relationship between a service provider an customer to work, they must be mutually satisfactory value propositions offered by both parties; what they term 'reciprocal' value propositions (Vargo \& Lusch, 2004 ; Ballantyne \& Varrey, 2006). Hence, shifting away exclusively customer-brand relationship is replaced with the idea of all stakeholders co-create brand value (Merz et al. 2009) which is viewed as a continuous social 
process in which brand value is being co-created through stakeholder-based negotiations (Muniz \& O’Guinn, 2001; Brodie et al. 2011).

\subsection{Customer role clarity}

The literature shows that role clarity is an important part of organizational citizenship behavior which consists of 'in-role' and 'extra-role' behaviors (Siddhart \& Agrawal, 2014). But today, it is not limited to organizational behavior, but also applicable in consumer behavior, especially because the effects of varying degrees of ambiguities or conflicts in student roles that can lead to tensions, frustration and disloyalties. Drawing from the role theory, role clarity is not new to marketing, but very little attention is given towards customer role identity in service context, despite support for the reciprocal involvement of providers and customers in service encounters (Yousefian, 2015). With now the focus on co-creation, students in HEIs functioning as "partial employee", this behavior can positive or negative in nature. Either way, the role students play is purely voluntary and discretionary when it comes to helping others, following rules and supporting the brand objectives (Stoner et al. 2011).

In reference to role identity theory, performing extra-role behavior is referred to "component of the self that correspond to the social roles we play" (Stoner et al. 2011). This theory is critical to the study of extra-role behaviors firstly because it emphasizes on social relations and role expectation; secondly it reflects the internalized role expectation of others. However, role clarity has also been classified as consumer readiness (Meuter, Bitner, Ostrom \& Brown, 2005; Yoo, Arnold \& Frankwich, 2012) and consumer identification (Keh \& Xie, 2009).

While customer readiness is focus on the willingness of consumers to take on the role to share their thoughts and feelings with others, consumer brand identifications is defined as the degree to which the brand expresses and enhances consumer identity (Tuskej, Golob \& Podnar. 2013). But if consumers feels that their effort level will lead to goal attainment or rewards is valued by the individual, the willingness to engage in advocacy behavior is higher. Hence understanding and analyzing customer knowledge is a key driver to create customer equity. However, in doing so, HEI must ensure constant communication on not only expected in-role behavior, but also triggering consequences of consumer extra-role duties. While, managing 'in-role' behavior of students is within the control of HEIs by setting guidelines, rules, regulations and systems, the 'extra-role' behavior of students is discretionary. The extra-role behavior in role clarity is defined when a person "goes beyond existing role requirement" (Siddhart \& Agrawal, 2014). It's something beyond the call of duty or the requirements set by service providers. The extra role behavior is argued to be part of citizenship behavior as soon as the level of engagement in a certain behavior exceed the minimum standards required by customers (Siddhart \& Agrawal, 2014)..

In fact, students may identify with the brand not only for self-definition purposes but also self-referrals (Keh \& Xie, 2009). Hence, the concept of role clarity from consumer perspective is pivotal towards the understanding corporate reputation, behavioral intentions, willingness to pay premium price (Keh \& Xie, 2009) and citizenship behavior (Yi \& Gong, 2013; Bataineh, Alfafah, Falah \& Idris, 
2017). In the age of co-creation value, the customers requires clarity in roles they can undertake as a customer, especially when they go on to become independent value creators. The role theory was related to role clarity by means of knowledge and understanding of what to do and what must be performed (Medberg, 2016). Role clarity or ambiguity operationalized from an objective perspective refers to the presence or absence of adequate role-relevant information due either to restriction of this information or to variation of the quality of information, while subjective feeling of having as much or not as much role-relevant information as the person would like to have (Lyon, 1971). However, the author further highlights both types tend to measure role clarity that relates to satisfaction and reduced tension, thereby increasing brand trust. In fact the authors' observation becomes more pertinent considering the fact that Asians are characteristically quite communal in nature, leading towards advocacy (Kotler et al. 2017).

For example in the context of students of HEIs, it is pivotal that they need to know how to use the services and facilities, what is expected of them, how much authority they have, what responsibilities they, how to deal with support staff and academic staff. However, it is no doubt, they will eventually go on to communicate with customers outside institutions, hence it is important that students are equipped with the right knowledge and information, and are familiar with their roles to avoid ambiguities and conflicts which bring about negative consequences on brand value (Meuter et al. 2005). When students proudly refer to themselves as a graduate, it's a way of showing that they are proud being part of the brand, and therefore spreading positive word-of-mouth or even being resilience to negative information associated with the brand (Keh \& Xie, 2009) becomes part of their extra role behavior in perceiving value-in-use (Meuter et al. 2005). But sometimes consumers may have ambiguity if they subjectively perceive the information, rules, systems are not transparent and are not getting what they wish; or even the relevant knowledge is not properly cascaded, leading to some ambiguity of their expected roles. This can also be negatively associated with their perception and will impact on future cocreations. In fact today, customers equip with high levels of brand knowledge are considered as catalyst for role clarity (Bataineh et al. 2017). With clear and confident about their student roles in their institution, they may feels highly belong to their institution, that will eventually show loyalty behavior (Mukherjee \& Malhotra, 2006).

\subsection{Customer trust and commitment}

Trust has traditionally been considered as a key variable for long lasting relationships and as a preceding state for the development of commitment. It was defined as a as "a willingness to rely on an exchange partner in whom one has confidence" (Sanchez-Fernandez et al. 2010). Then it was further extended by highlighting that students' trust in educational institution can be understood as their confidence in its integrity and reliability, and it is based on the personal experiences of students with faculty members (Morgan \& Hunt, 1994; Hennig-Thurau, Gwinner \& Gremler, 2002). Later, trust was defined as "customer's belief that a firm is reliable, stand by its word, fulfil its promised obligations, and is sincere" (Yousefian, 2015). It was further stated trust is formed in three processes: prediction, intentionality and capability. While the prediction process of trust 
focuses on individual belief on the ability to forecast a firm's future action, intentionality relates to individual's ability to interpret benevolence resulting firm's prior actions, and capability focuses on individual's ability to assess firm's competency to meet obligation to customers. The focus of intentionality of students in HEIs are crucial as it's a prediction towards their future behavior, when cocreating with others in the network. Drawing from the commitment-trust theory, there is a major shift in the theory whereby the focus now is in the buyer partnership relationship which requires focus on establishing, developing, and maintaining successful relationship exchanges (Morgan and Hunt, 1994). The theory used in KMV of relationship model comprising of shared values, communication and opportunistic behavior explained how trust can lead to relationship commitment by having open communication and shared values (Morgan and Hunt, 1994). In addition to that, customer trust can be also from the level of reliability ensured by one party to another within a given exchange relationship (Nguyen, Leclerc \& LeBlanc, 2013).

This affirms trust creates value because it provides relational benefits which is derived from the constant interaction between the service provider and consumers, and this in turn will reduce uncertainties, ambiguities and conflicts in the minds of consumers (Sanchez-Fernandez et al. 2010). Its roots from social exchange theory shows that commitment is an exchange party's long term desire to maintain a valuable ongoing relationship with another (Keh \& Xie, 2009), but it was also highlighted in the context of services marketing, relationship is on the basis of mutual commitment (Berry \& Parasuraman, 1993). For service marketing to be effective, managing trust is crucial as customer typically buy a service before experiencing it" (Keh \& Xie, 2009). For example, a customer engaging with other potential customers in a positive note, endorsing the brand depicts a sense of commitment to the brand. Hence, today customer commitment is defined as an exchange partner's willingness to maintain an important enduring relationship, which could extend ViU through co-creation value with other stakeholders (HennigThurau et al. 2002).

\subsection{Self-brand connection}

Two of the most important properties to brand attachment are brand-self connection and brand prominence (Park, Macinnis, Priester, Eisingerich \& Iacobucci, 2010). Both these antecedents are important as its measures the "strength" of the bond connecting the brand with the consumer, which will ultimately result in not only repurchase behavior but also to engage in relationship-sustaining behavior. This could lead to greater behavioral commitment in the form of brand loyalty and other behaviors such as positive word-of-mouth, more time, money and energy spent on the relationship.

Self-brand attachment is defined as the strength of the bond connecting the brand with the self, which is consistent with attachment theory (Park et al. 2010). It involves thoughts and feelings about the brand and the brand's relationship to the self and focuses on aspects of attachment which involves cognitive and emotional connection between the brand and self. Furthermore, brand attachment concept also share some conceptual resemblance to brand relationship quality (BRQ), as brandself connection is also one of the six indicators (Fournier, 1998). The other five 
indicators of BRQ are commitment, love/passion, intimacy, and interdependence and brand partner quality. However, the attachment can vary in strength, whereby stronger attachments are associated with stronger feelings of connection, affection, love, and passion (Thomson, MacInnis \& Park, 2005). With students acting as "partial employees", it clearly shows students are involved in a business relationship with the brand and a shopper relationship with the consumer by providing information (Fournier 1998).

In any co-creation circumstances, especially in the context of stakeholderfocus brand era, the responsibility of a brand value is heavily dependent on the relationships between the consumers and brand. Hence, consumer's commitment to the brand must be viewed as a psychological attachment whereby the impact of their readiness to spend more effort in order to reach the brand goal (Bataineh et al. 2017). In the context of students, it is important that the institution instill a feelings of being proud and belonging to the university could be imperative. When students depict high levels of psychological attachment to the brand, it will high level of commitment of students and this is an important variable in advocacy, which is part of consumer citizenship behavior.

\subsection{Brand Prominence}

Another property of brand attachment is brand prominence, while has some variation from self-brand connection. When consumers become highly attached are more motivated to devote their own resources to the process of self-expansion, including paying more, defending the brand, derogating alternatives, and devoting more time to the brand through brand communities and brand promotion through social media, then brand prominence is evident (Raut, 2015). Brand prominence suggests the extent to which positive feelings and a memory about the attachment is perceived as top of mind and services as an indicator or attachment (Park et al. 2010).

Brand prominence is an important variable towards understanding attitude strength in terms of consumer ability to predict separation anxieties (Raut, 2015). Furthermore, this variable may serve as an important indicator of attachment when consumers are connected to a brand because of its instrumental value (i.e., a person's iMac is important in fulfilling entertainment- and work-related goals). That is, when a brand has instrumental value, attachment should be stronger when brandrelated thoughts and feelings are more versus less prominent (Park et al. 2010). In the context of HEI, this process may take time, but with the number of hours a student spends at an institution, this may not be impossible. This can also be example from the concept of love (Shrimp \& Madden, 1988), thereafter coming up with the Triangular theory of Love which is made up of three components: intimacy, passion and commitment (Sternberg, 1986). While intimacy refers to the closeness and warmth that is felt within the relationship, passion focuses on the physical drives that lead to arousals, while commitment refers to the decision to be committed to a loving relationship (Sternberg, 1986). 


\subsection{Conclusion}

The choice for customer to be involved in advocacy behavior on any brand has a significant impact on any organizational performance and image. In an age whereby consumers are relying on word-of-mouth of others, it has become critical for organisations, especially service based companies such as Higher Learning Institutions to convert students to advocates, rather than detractors. But first and foremost, in order to influence customer advocacy behavior, students must first have a clear understanding of their 'in-role' and 'extra-role' duties which forms role clarity (Stoner et al. 2011). With role clarity, ambiguities and conflicts can be reduced in view of influencing students' ability to act on behalf of the identity of an institution (Stoner et al. 2011). Another important factor is trust. Trust is an important factor in the relationships between customers and organizations. It is especially pivotal in successful service relationships (Parasuraman, Zeithaml \& Berry, 1985). It was also suggest that customer trust should be regarded as an antecedent when studying existing customers (Brodie et al. 2011). This is especially because students aspire to have relationships with brands they can trust, share values with, and deem to be socially responsible; secondly engaging in relational behavior with the brands is to also reduce perceived risks and achieve greater efficiency and consistency in their decision making (Jillapalli \& Wilcox, 2010). When students have clarity in how to perform their extra role duties and trust, a level of attachment with the brand in the form of self-brand connection which is top-of-mind may happen over time (Fournier, 1998). Therefore, it is encouraged for HEIs to explore these factors in understanding of their students' commitment towards the brand. As part of internal branding efforts, HEIs must recognize students will eventually become graduates, and they relate to the brand at a degree to which the brand expresses and enhances consumer's identity (Tuskej et al. 2013).

This study also indicates that it may useful to other work institutions for example, brand managers and senior officials , the higher education government bodies, customer services to recognize that the advocacy behavior of any customer is a way of endorsing the brand for others to have confidence in the brand.

\section{References}

Anholt, S. (2010) Places: Identity, image and reputation. Houndsmills, United Kingdom: Palgrave Macmillan.

Ballantyne, D. \& Varey, R.J. (2006) Creating value-in-use through marketing interaction: the exchange logic of relating communicating and knowing, Marketing Theory, 6, 335

Baron, S., Patterson, A., Warnaby, G. \& Harris, K. (2010) Service dominant Logic: marketing research implications and opportunities, Journal of Customer Behaviour, 9, 253264

Bataineh, A.Q., Alfalah, T.F., Falah, J.F. \& Idris, M.I. (2017) The Effect of Employee-Based Brand Equity on Organisational Citizenship Behavior: The Mediating role of Job Satisfaction, International Journal of Academic Research in Business and Social Sciences, $7(2), 423-436$ 
Berry, L.L. \& Parasuraman, A. (1993) Building a New Academic Field-The Case of Services Marketing, Journal of Retailing, 69 (1), 13-60.

Brodie, R. J., Hollebeek, L. D., Juric, B. \& Ilic, A. (2011) Customer Engagement: Conceptual Domain, Fundamental Propositions, and Implications for Research. Journal of Service Research, 14, 252-271

Edvardsson, B., Enquist, B., \& Johnston, R. (2010). Design dimensions of experience rooms for service test drives: case studies in several service contexts. Managing Service Quality, 20(4), 312-327.

France, C., Merrilees, B. \& Miller, D. (2015) Customer brand co-creation: a conceptual model. Marketing Intelligence \& Planning 33:6, 848-864.

Fournier, S. (1998). Consumers and their brands: developing relationship theory in consumer research. Journal of Consumer Research, 24(4), 343-353.

Fugetta, R. (2012) Top 10 ways to "sell" a brand advocate program to your CMO https://zuberance.com/zuberrants/blog/top-10-ways-to-sell-a-brand-advocate-program-toyour-cmo

Garas, S.R.R., Mahran, A,F.A. \& Mohamed, H.M.H (2018) Internal corporate branding impact on employees' brand supporting behaviour. Journal of Product \& Brand Management 27:1, 79-95.

Gronroos, C. and Voima, P. (2013) Critical Service Logic: Making Sense of Value Creation and Co-creation, Journal of the Academy of Marketing Science, 41(2), 133-150.

Hennig-Thurau, T., Gwinner, K. P., \& Gremler, D. D. (2002). Understanding relationship marketing outcomes: An integration of relational benefits and relationship quality. Journal of Service Research,

Jillapalli, R. K., \& Wilcox, J.B. (2010) Professor Brand Advocacy: Do Brand Relationships Matter? Journal of Marketing for Higher Education, 32(3), 328-340

Keh, H.T. \& Xie, Y. (2009) Corporate reputation and customer behavioral intentions: The roles of trust, identification and commitment. Industrial Marketing Management, 38 7: 732742

Kemp, E., Childers, C.Y. \& Williams, K.H. (2012),"Place branding: creating self-brand connections and brand advocacy", Journal of Product \& Brand Management, Vol. 21 Iss: 7 pp. $508-515$

Kirby, J. \& Marsden, P. (2016) Connected Marketing: the viral, buzz and word of mouth revolution.

Kotler, P., Kartajaya, H. \& Hooi, D.H. (2017) Marketing for Competitiveness: Asia to the World: In the Age of Digital Consumers

Kotler, P., Kartajaya, H. \& Setiawan, I. (2016) Marketing 4.0: Moving from traditional to digital

Lawer, C., \& Knox, S. (2006). Customer advocacy and brand development. Journal of Product and Brand Management, 15(2), 121-129. 
Lovelock, C.H. \& Wirtz, J. (2007) Services marketing: people, technology, strategy (6. ed.). Upper Saddle River, NJ: Pearson/Prentice Hall.

Lowenstein, R. (2012) The customer advocate and the customer saboteur: Linking Social Word-of-mouth, brand impression and stakeholder behavior, American Society for Quality, Quality Press, Milwaukee.

Lyons, T.F. (1971) Role clarity, need for clarity, satisfaction, tension and withdrawal”, Organisational Behaviour and Human Performance, Vol. 6, pp. 99-110.

Medberg, G. (2016) How Do Customer Perceive Value-In-Use? Empirical Insights from Bank Service Stories, Helsinki, PhD thesis

Merz, M.A., Yi, H. and Vargo, S.L. (2009) The evolving brand logic: a service-dominant logic perspective, Journal of the Academy Marketing Science

Meuter, M. L., Bitner, M. J., Ostrom, A. L., \& Brown, S. W. (2005). Choosing among alternative service delivery modes: An inves- tigation of customer trial of self-service technologies. Journal of Marketing, 69(2), 61-83.

Morgan, R. M., \& Hunt, S. D. (1994). The commitment-trust theory of relationship marketing. Journal of Marketing, 58, 20-38

Mukherjee, A. \& Malhotra, N. (2006) Antecedents and consequences of role clarity in explaining employee- perceived service quality in call centers Does role clarity explain A study of antecedents and consequences, International Journal of Service Industry Management 17(5)

Muniz, A., \& O'Guinn, T. (2001). Brand Community. Journal of Consumer Research, 27(4), 412-432, March.

Nguyen, N., Leclerc, A. \& LeBlanc, G. (2013) The Mediating Role of Customer Trust on Customer Loyalty. Journal of Service Science \& Management, 6, 96-109.

Ostrom, A. L., Bitner, M. J., Brown, S.W., Burkhard, K. A., Goul, M., Smith-Daniels, V., \& Rabinovich, E. (2010). Moving forward and making a difference: research priorities for the science of service. Journal of Service Research, 13(1), 4-36.

Park, C. W., Macinnis, D., Priester, J., Eisingerich, A. \& Iacobucci (2010) Brand Attachment and Brand Attitude Strength: Conceptual and Empirical Differentiation of Two Critical Brand Equity Drivers, 74, 1-17.

Parasuraman, A., Zeithaml, V. A. \& Berry, L. L. (1985) A conceptual-model of service quality and its implications for future-research. Journal of Marketing, 49, 41-50.

Park, C. W., Macinnis, D., Priester, J., Eisingerich, A. \& Iacobucci, D. (2010) Brand Attachment and Brand Attitude Strength: A conceptual and empirical differentiation of two critical brand equity drivers, (74), 1-17

Prahalad, C. K., \& Ramaswamy, V. (2000) Co-opting customer competence. Harvard Business Review, 78(January- February), 79-87 
Payne, A., Storbacka, K., Frow, P., \& Knox, S. (2009). Co-creating brands: Diagnosing and designing the relationship experience. Journal of Business Research, 62(3), 379-389.

Payne, A. \& Frow, P. (2011) A stakeholder perspective of the value proposition concept, European Journal of Marketing, 45, 1/2, 223-240

Phadke, S. ., \& Bhagwat, V. (2011). Insight Into Undergraduate Business Students , Perception of Education Service Quality and Value. International Journal of Multidisciplinary Management Studies, 1(3), 1-8.

Ranjan, K.R \& Read, S. (2016) Value co-creation: concept and measurement, Journal of the Academy of Marketing Science, pp. 1-26

Raut, U.R. (2015) Analysis of Brand Resonance Amongst Young Consumers With Reference To Select Product Categories < https://repositorioaberto.up.pt/bitstream/10216/81339/2/37103.pdf>

Rosenbaum-Elliott, R., Percy, 1 \& Pervan, S (2011) Strategic Brand Management, $2^{\text {nd }}$ ed, Oxford University Press

Sanchez-Fernandez, iniesta- Bonillo, M.A., Schlesinger-Diaz, W., Rivera-Torres, P. (2010) Analysis of value creation in higher education: relational perspective.

Skoog, M. and Söderström, M. (2015) Antecedents and outcomes of brand love: a qualitative study within the Swedish clothing industry. <http://www.divaportal.org/smash/get/diva2:841971/FULLTEXT01.pdf>

Shimp,T. A.,\& Madden,T. J. (1988). Consumer-object relations: A conceptual framework based analogously on Sternberg's triangular theory of love. Advances in Consumer Research, $15,163-168$.

Siddhart, N. \& Agrawal, R. (2014) Exploring Role Efficacy as correlate to Organizational Citizenship Behaviour among Female Nurses in a Maternal and Childcare Facility, Journal of Business Management, 13(2), 53-70

Sternberg, R. J. (1986). A triangular theory of love. Psychological Review, 93, 119-135.

Stoner, J., Perrewé, P.L. \& Munyon, T.P. (2011) The role of identity in extra-role behaviors: development of a conceptual model, Journal of Managerial Psychology, 26(2), 94-107

Susanta, Alhabsji, T., Idrus, M.S. \& Nimran, U. (2013) The Effect of Relationship Quality on Customer Advocacy: The mediating role of loyalty, Journal of Business and Management, 10(4), 51-52

Tapsir, S. (2016). A strategy for the next decade of Malaysian higher education. Ministry of Higher Education - Government of Malaysia ACU Perspective. < https://www.acu.ac.uk/events/perspectives/datin-siti-hamisah-presentation>

Teng, R. (2016) The quality of private education in Malaysia http://www.theedgemarkets.com/article/quality-private-higher-education-malaysia)

Thomson, M., MacInnis, D. J., \& Park, C.W. (2005). The ties that bind: measuring the strength of consumers' emotional attachments to brands. Journal of Consumer Psychology, 15(1), 77-91.

Tuskej, S., Golob, U. \& Podnar, K. (2013) The role of consumer-brand identification in building brand relationships, Journal of Business Research 66, 53-59 
Vargo, S.L., \& Lusch, R.F. (2004). Evolving to a New Dominant Logic for Marketing. Journal of Marketing, 1-17.

Vargo, S.L. and Lusch, R.F. (2011) Value propositions in higher education - an S-D logic view

Walz, A. M. \& Celuch, K. G. (2010). The Effect of Retailer Communication on Customer Advocacy: The Moderating Role of Trust. Journal of Consumer Satisfaction, Dissatisfaction and Complaining Behavior, 23: 95-110.

Warwick, P. (2016) An integrated leadership model for leading education for sustainability in higher education and the vital role of students as change agents, Management in Education, 30(3),105-111.

Xie, C., Bagozzi, R.\& Troye, S. (2008) Trying to prosume: toward a theory of consumers as co-creators of value, Journal of the Academy of Marketing Science, 36 (1), 109-122.

Yi, Y., \& Gong, T. (2013). Customer value co-creation behavior: Scale development and validation. Journal of Business Research, 66(9), 1279-1284.

Yousefian, J. (2015) The Effect of Self-efficacy , Role Clarity, and Trust on Customer Wellbeing and Loyalty through Value Co-creation: The Case of Fitness Centres, University of Hul, Docto

Yoo, J., Arnold, T. J. \& Frankwich, G. L. (2012) Effects of positive customer-to- customer service interaction. Journal of Business Research, 65, 1313-132 